\title{
Sentralnervesystemets mekanismer for smertehemming
}

\begin{abstract}
Sammendrag
Bakgrunn. Opplevelsen av smerte reguleres av flere endogene faktorer. Kunnskapen om endogene smertehemmende mekanismer er økende. Forståelse av disse mekanismene er nyttig både for leger som behandler pasienter med smerter og for forskere med fokus på smertefysiologi. I denne artikkelen ønsker vi å gi en oppdatert oversikt over disse mekanismene.
\end{abstract}

Materiale og metode. Denne oversiktsartikkelen er bygd på et ikke-systematisk søk i PubMed med et skjønnsmessig utvalg av artikler basert på forfatternes erfaringer.

Resultater. Endogene smertehemmende mekanismer er i hovedsak knyttet til ulike deler av retikulærsubstansen og aktiveres normalt ved smertefull stimulering. Forventning om smertereduksjon (placeboanalgesi), samtidig smertefull stimulering andre steder og høyt blodtrykk er eksempler på faktorer som kan øke kroppens endogene smertehemmende mekanismer. Opioidsensitive celler i hjernestammen er viktig for endogen smertehemming. Redusert endogen smertehemming er funnet ved en lang rekke kroniske smertefulle tilstander, men det er ikke avklart hvorvidt redusert endogen smertehemming er en årsak til eller et resultat av kroniske smerter.

Fortolkning. Forsterkning av kroppens endogene smertehemmende mekanismer er mulig og potensielt nyttig $i$ behandling av pasienter med smerter.

\author{
Kristian Bernhard Nilsen \\ kristian.b.nilsen@ntnu.no \\ Seksjon for klinisk nevrofysiologi \\ Avdeling for nevrologi \\ Oslo universitetssykehus \\ 0407 Oslo \\ og
}

Institutt for nevrovitenskap

Norges teknisk-naturvitenskapelige universitet

\section{Magne Arve Flaten}

Institutt for psykologi

Universitetet i Troms $\varnothing$

\section{Knut Hagen}

Avdeling for nevrologi og nevrofysiologi

St. Olavs hospital

og

Institutt for nevrovitenskap

Norges teknisk-naturvitenskapelige universitet

\section{Dagfinn Matre}

Statens arbeidsmiljøinstitutt

Trond Sand

Avdeling for nevrologi og nevrofysiologi

St. Olavs hospital

og

Institutt for nevrovitenskap

Norges teknisk-naturvitenskapelige universitet

Smerter er et stort problem for mange pasienter. Kunnskap om smertemekanismer er viktig for klinikere som ønsker å gi god smertebehandling. En inngående forståelse av smertefysiologi er også viktig for å kunne drive god forskning innen området. I denne artikkelen beskriver vi kjente sentralnervøse mekanismer for hemming av smerte.

\section{Materiale og metode}

Gjennomgangen er basert på et ikke-systematisk søk i PubMed med et skjønnsmessig utvalg av artikler basert på forfatternes erfaringer gjennom egen forskning på smertefysiologi.

\section{Historikk}

Opplevelsen av smerte er avhengig av både eksterne og endogene faktorer. Tidligere mente man at opplevelsen av smerte ble formidlet uavbrutt til hjernen etter perifer smertefull stimulering. Etter at Melzack \& Wall i 1965 introduserte smerteportteorien, endret denne forståelsen seg (1). Selv om denne teorien forenkler virkeligheten, har selve ideen om at smertesignalene kan moduleres vist seg å være nyttig. Med modulering menes hemming eller forsterking på ulike nivåer i sentralnervesystemet. Smerteportteorien kan for eksempel brukes som modell for å forklare effekten av transkutan smerte- stimulering. Sentralt i denne modellen er at stimulering av tykke myeliniserte nervefibre $(\mathrm{A} \beta)$ vil inhibere den synaptiske overgangen mellom smerterelaterte tynne nervefibre (A $\delta$ - og C-fibre) og projeksjonsnevroner i sentralnervesystemet. Modellen inkluderer også påvirkning fra sentralnervesystemet, selv om dette aspektet ikke alltid har kommet like mye frem i de mange forenklede fremstillingene. Dagens forståelse av hvordan aktivitet i smertespesifikke nerveledningsbaner moduleres, er på mange måter en utvidelse av smerteportteorien. Smerterelaterte nerveledningsbaner kan potensielt også moduleres perifert, men en beskrivelse av dette er for omfattende for denne artikkelen.

De endogene smertehemmende mekanismene (ramme 1) er noe bedre forstått enn de smerteforsterkende mekanismene, og vi vil i det følgende gå nærmere inn på de smertehemmende mekanismene og de potensielt klinisk nyttige aspektene av disse.

\section{Relevante anatomiske områder}

De viktigste av de nevnte nervebanene er vist i figur 1. Smerte er en sentralnervøs fortolkning av nervesignaler fra perifere strukturer. Signalkjeden starter perifert i de primære afferente nervefibrene (i hovedsak $\mathrm{A} \delta$ - og $\mathrm{C}$-fibre). Signalene formidles videre gjennom projeksjonsnevroner som hovedsaklig går opp gjennom kontralateral del av ryggmargens fremre og laterale deler (tractus spinothalamicus) med synaptiske forbindelser i thalamus. Signalene går videre til ulike sentralnervøse områder som sammen gir en smerteopplevelse med både sensorisk diskriminative, affektive og kognitive elementer.

Det er i de synaptiske overgangene nervebanene er tilgjengelig for modulering. Smerterelaterte nerveledningsbaner har synaptis-

\section{Hovedbudskap}

- Sentralnervesystemet kan redusere smerteopplevelsen som er knyttet til en gitt smertefull stimulus

- Endogene smertehemmende mekanismer forsterkes ved f.eks. positiv forventning (placebo) og smertefull betinget stimulering

- Kunnskap om endogene smertehemmende mekanismer er potensielt nyttig i en behandlingssituasjon 


\section{Ramme 1}

\author{
Eksempler på endogene \\ smertehemmende mekanismer: \\ Placeboanalgesi (reduksjon av forven- \\ tet smerte virker analgetisk) \\ Smertefull betinget stimulering (diffus \\ nociseptiv inhiberende kontroll) \\ Hypertensjonsrelatert hypoalgesi \\ (høyt blodtrykk virker analgetisk) \\ Mosjonsindusert analgesi (kortvarig \\ effekt etter høy intensitet) \\ Distraksjon
}

ke forbindelser i ryggmargens dorsalhorn og i thalamus. Kunnskap om de anatomiske områdene som er relevante for endogen smertehemming, kommer i det vesentlige fra forsøk gjort på dorsalhorn i rotter og mus. Det er ukjent i hvilken grad synapsene i thalamus kan moduleres. Perifere smerterelaterte nervefibre har synapser i flere av dorsalhornets lamina. Det meste av det vi vet om endogen smertehemming gjelder modulering av cellene i lamina I-II. Disse cellene blir modulert både av internevroner lokalisert på samme nivå i ryggmargen og nedadstigende nervebaner fra mesencefalon, pons og hjernestammen (2).

Periakveduktal grå substans (PAG) i mesencefalon er svært viktig for initiering av endogen smertehemming. Fibre fra periakveduktal grå substans har synaptiske forbindelser blant annet med celler i retikulærsubstansens ventrale og mediale del i overgangen mellom pons og hjernestammen, ofte kalt rostrale ventromediale medulla (RVM). De langstrakte rafekjernene går gjennom dette området, og de ikke-serotonerge cellene i rafekjernene som er av betydning for endogen smertehemming omtales gjerne under ett, uavhengig av om de blir klassifisert som tilhørende rostrale ventromediale medulla eller rafekjernene. Celler i dette området av betydning for endogen smertehemming har nevroner som projiserer til ryggmargens dorsalhorn og benevnes oneller off-celler avhengig av om de reduserer (off) eller forsterker (on) aktiviteten i smerterelaterte projeksjonsnevroner i ryggmargens dorsalhorn. Morfin inhiberer on-celler og aktiverer off-celler (3).

Fibre fra periakveduktal grå substans har også synaptiske forbindelser med kjerner i dorsolaterale pontine tegmentum (DLPT). Som navnet antyder, ligger denne baktil og lateralt øverst i pons, der vi blant annet finner locus coeruleus. Aktivering av disse kjernene $\mathrm{i}$ pons vil redusere aktiviteten $\mathrm{i}$ smerterelaterte projeksjonsnevroner i ryggmargens dorsalhorn (4).

Andre deler av retikulærsubstansen som er av betydning for endogen smertehemming, er subnucleus reticularis dorsalis (SRD), ventrolaterale medulla (VLM), rafe- kjernene og nucleus tractus solitarius (NTS). Subnucleus reticularis dorsalis ligger nederst i retikulærsubstansen, mellom trigeminuskjernene og nucleus tractus solitarius, og benevnes ofte «dorsal reticular nucleus» (DRt). Aksoner fra dette området har synaptiske forbindelser med smerterelaterte fibre ipsilateralt i dorsalhornet og er sentrale i den endogene antinociseptive mekanismen vi kjenner som «diffuse noxious inhibitory controls» (DNIC) fra dyreforsøk (5). Begrepet er vanskelig å oversette direkte til norsk, men vi foreslår at begrepet kan omtales som diffus nociseptiv inhiberende kontroll.

Ventrolaterale medulla ligger i medulla, opp mot pons og lateralt for de opioidsensitive cellene i rostrale ventromediale medulla. Dette området er sentralt i styringen av det autonome nervesystemet og er i denne sammenhengen viktig for det vi kjenner som hypertensjonsrelatert hypoalgesi.

Nucleus tractus solitarius er kjent som den primære reléstasjonen for afferente signaler fra det autonome nervesystemet. Rafekjernene ligger tett inntil og medialt for rostrale ventromediale medulla og projiserer både til preganglionære autonome nervefibre og til ryggmargens dorsalhorn.

\section{Endogene smertehemmende mekanismer}

Smertestimulering vil i seg selv aktivere kroppens endogene smertehemmende mekanismer. Smertens kvalitet og styrke bestemmes av aktiviteten i smerterelaterte nerveledningsbaner og subjektive faktorer som for eksempel stemningsnivå, tidligere erfaringer og i hvilken grad smerten oppfattes som en fare eller trussel. Avhengig av hvordan personen som utsettes for den smertefulle stimulus vurderer smertens signifikans, vil forbindelser fra ulike sentralnervøse områder kunne påvirke periakveduktal grå substans, som igjen via sine forbindelser til ventrolaterale medulla og dorsolaterale pontine tegmentum vil kunne modulere videre smertepersepsjon.

\section{Placeboanalgesi}

Placeboanalgesi er den smertereduserende effekten av forventning om smertereduksjon etter en gitt behandling/intervensjon. Det vesentlige for fenomenet placeboanalgesi er en forventning om smertereduksjon. Eksempelvis blir postoperative smerter redusert langsommere og dårligere dersom pasienten ikke får vite at behandling (intravenøs morfin) er satt i gang, i forhold til om pasienten blir informert om når behandlingen starter (6). En forbehandling, eller effektsimulering/ lurebehandling, gir en tilleggseffekt (7). Forventninger om reduksjon i smerteopplevelse etter inntak av placebo er assosiert med aktivitet i prefrontale cortex (8) og kan måles som en reduksjon av mekanisk sekundær hyperalgesi rundt et brannsår (9). Sistnevnte er en indikasjon på redusert sensitivisering av projeksjonsnevroner i dorsalhornet. Placeboanalgesi synes $i$ hovedsak å være me- diert gjennom endogene opioider (10). Opiatantagonister blokkerer imidlertid ikke placeboanalgesi fullstendig, hvilket indikerer at andre faktorer også spiller en rolle. Periakveduktal grå substans og rostrale ventromediale medulla er viktige elementer i placeboanalgesi. Studier med bruk av positronemisjonstomografi (PET) og funksjonell magnetresonansavbildning (fMRI) på mennesker indikerer at placeboanalgesi aktiverer både kortikale områder og de opioidsensitive cellene i rostrale ventromediale medulla (11). Effekten av placeboanalgesi blir den samme som ved morfinbehandling med reduksjon av smerterelatert aktivitet i dorsalhornet og i smerterelaterte kortikale områder.

\section{Noceboeffekt}

Tilsvarende til placeboanalgesi kan man ha en smertefasiliterende effekt (nocebo) ved en forventning om smerteøkning ved en gitt behandling/intervensjon. Noceboeffekten kommer av økt frykt og angst når personen blir fortalt at noe vil giøre vondt eller bli enda vondere, og involverer økt aktivitet i smerterelaterte områder i hjernen, det vil si en negativ placeboeffekt (12). Legemidler som reduserer angst og frykt, reduserer også nocebohyperalgesi (13).

\section{Smertefull betinget stimulering}

Ved å påføre smerte et sted på kroppen kan man redusere smerteopplevelsen andre steder på kroppen (smertefull betinget stimulering). Fenomenet tilsvarer det en kjenner fra dyreforsøk som diffus nociseptiv inhiberende kontroll og innebærer smertereduksjonen som består etter at den betingede stimuleringen er over, noe som indikerer at fenomenet ikke forklares av distraksjon alene. Den diffus nociseptiv inhiberende kontroll-liknende effekten som man ser ved smertefull betinget stimulering er vist å være funksjonelt knyttet til nederste del av retikulærsubstansen (SRD) (5), men har også rene cerebrale komponenter (14). Det er en viss uenighet om hvorvidt denne mekanismen er opioidavhengig (15), men det synes å være enighet om at denne mekanismen er uavhengig av den ovenfor beskrevne aksen mellom periakveduktal grå substans og rostrale ventromediale medulla. Smertefull betinget stimulering $\mathrm{i}$ forskjellige varianter er mye brukt $\mathrm{i}$ studier av endogen smertehemming på mennesker (16). Også ikke-smertefulle betingede stimuli kan gi en viss effekt som likner diffus nociseptiv inhiberende kontroll.

\section{Hypertensjonsrelatert hypoalgesi}

Høyt blodtrykk kan gi analgesi. Dette kalles hypertensjonsrelatert hypoalgesi og er et konsistent fenomen som er vist både i dyrestudier (17), eksperimentelle humane studier (18) og i epidemiologiske studier (19). Dette kan forklare at hypertensive pasienter i mindre grad enn normotensive har smerter ved hjerteinfarkt (20). Hvilke funksjonelle forbindelser som er avgjørende for denne meka- 
nismen er ikke klarlagt, men ventrolaterale medulla er antatt å være svært sentral (21).

\section{Distraksjon}

Distraksjon kan også påvirke smerteopplevelsen. Smertens biologisk viktige rolle gjør at distraksjon ikke kan fjerne smerten fullstendig, men det er en kognitiv mestringsstrategi og reduserer både smertens intensitet og ubehag, sammenliknet med om oppmerksomheten rettes mot smerten $(22,23)$. De virksomme funksjonelle forbindelsene for distraksjonsanalgesi er ikke klarlagt.

\section{Mentalt stress}

Mentalt stress påvirker trolig opplevelsen av smerte, men resultatene spriker mer enn for de andre beskrevne mekanismene. Basert på tidlige dyrestudier har man lenge ment at akutt stress gir analgesi (24), og det har vært trukket analogier mellom disse studiene og beskrivelser av hvordan for eksempel soldater med skuddskader har forflyttet seg lange avstander uten å kjenne smerte så lenge stressnivået har vært høyt. Ut ifra nyere dyrestudier med mer affektivt/psykologisk orienterte endepunkter har man imidlertid trukket disse konklusjonene i tvil (25). I mange tidlige dyrestudier brukte man smertefulle stimuli for å indusere akutt stress. Sett i lys av det man nå vet om smertefull betinget stimulering, er det usikkert om den analgetiske effekten man så i disse tidlige studiene skal tolkes som et uttrykk for diffus nociseptiv inhiberende kontroll eller stressindusert analgesi. Det er holdepunkter for at det er stor forskjell på hvordan akutt stress og kronisk stress påvirker opplevelsen av smerte. Dyrestudier indikerer at kronisk stress kan virke smerteforsterkende (26). Forsøk på mennesker for å kartlegge mulige forbindelser mellom mentalt stress og smerte har gitt svært ulike resultater.

\section{Andre faktorer}

Andre faktorer som er antatt å kunne aktivere endogene smertehemmende mekanismer er steriltvannspapler, (is)kalde omslag, hypnose, musikk, akupunktur, humor, aromaterapi, massasje og avspenningsøvelser. Enkelte av disse metodene har en viss analgetisk effekt, men mekanismene er svært usikre (27). Det er rimelig å anta at bruk av steriltvannspapler og svært kalde omslag fungerer som smertefull betinget stimulering og derfor vil kunne gi kortvarig analgesi gjennom mekanismer som likner diffus nociseptiv inhiberende kontroll. Tilsvarende gjelder trolig også for behandling med isbading. Vi har imidlertid ikke funnet noen studier som har studert disse metodenes virkningsmekanismer systematisk.

Fysisk trening er også kjent for å kunne gi en viss analgesi, men treningen må i så fall være av betydelig intensitet, og effekten er relativt kortvarig (28).

Den analgetiske effekten av transkutan smertestimulering er antatt å skyldes aktivering av efferente smertehemmende baner. Me- kanismene i denne metoden er imidlertid ikke klarlagt i detalj. De fysiologiske mekanismene for kognitiv atferdsterapi er også uavklart.

Endelig er det vist at det også eksisterer intracellulære mekanismer med potensielt analgetisk effekt. Ved å regulere ekspresjonen av bestemte intracellulære proteiner $\mathrm{i}$ dorsalhornets projeksjonsnevroner kan effekten av den synaptiske forbindelsen mellom primære afferente nervefibre og projeksjonsnevroner påvirkes (29).

\section{Serotonin, rafekjerner og endogen analgesi} De serotonerge delene av rafekjernene og celler i nucleus tractus solitarius har også vist seg å bidra til endogen smertehemming (30), men mekanismene er mindre klarlagt for disse områdene. Selv om det er klare holde- punkter for at intratekalt serotonin har en smertehemmende effekt, har man ikke klart å påvise at de serotonerge fibrene fra rafekjernene er av betydning for denne effekten (31). Forbindelsene mellom rafekjernene, nucleus tractus solitarius og de andre sentrale smerterelaterte områdene er resiproke, og man kan derfor ikke utelukke at de serotonerge rafekjernene og nucleus tractus solitarius utøver sine smertehemmende funksjoner gjennom forbindelsen med de andre beskrevne områdene som er relevant for endogen smertehemming.

\section{Forsøk på dyr \\ er ikke forsøk på mennesker}

Både placeboanalgesi, hypertensjonsrelatert hypoalgesi og diffus nociseptiv inhiberende

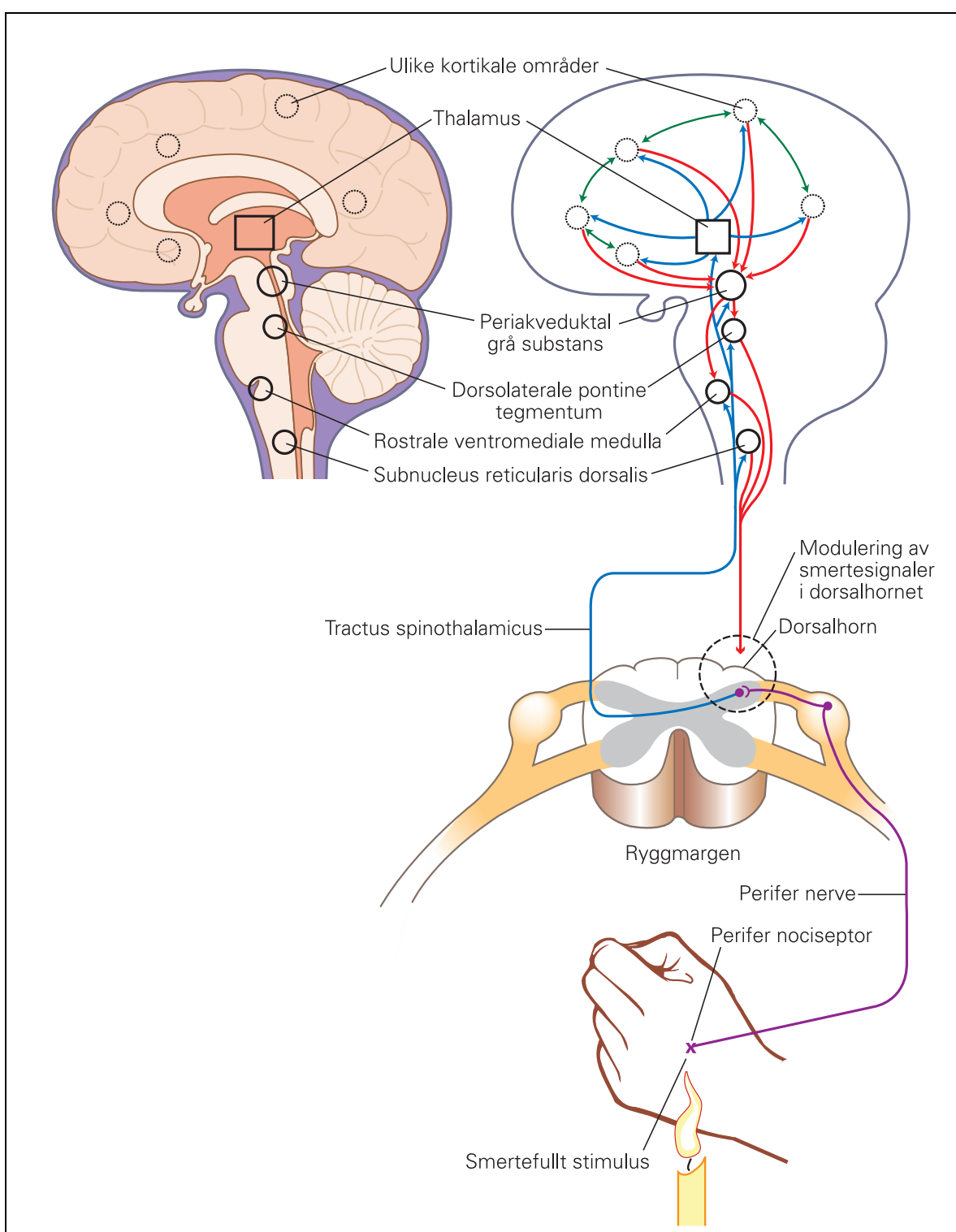

Figur 1 Et utvalgav nervebaner av relevans for endogen smertehemming. En afferent signalkjede av nervesignaler etter en smertefull stimulus (blå piler) har synaptiske forbindelser i dorsalhornet og i thalamus. De afferente nervebanene (tractus spinothalamicus) avgir forbindelser til ulike kjerner i pons/medulla før signalene når thalamus. Ulike efferente signalveier medvirker til modulering av smertesignalene i dorsalhornet (røde piler). De efferente modulerende signalveiene påvirkes i stor grad av den sentralnervøse tolkingen av smertens signifikans 
kontroll har vist seg å være konsistente fysiologiske fenomener hos mennesker. Imidlertid er det grunn til å understreke at det vesentlige grunnlaget for forståelsen av nevrobiologien bak disse fenomenene er basert på dyreforsøk der man har brukt surrogatmål på smerte eller målt aktivitet i smerterelaterte nervefibre (nocisepsjon). Dette er ikke det samme som human smerte, som er en mer kompleks kognitiv opplevelse.

Kunnskapen vi har om sannsynlige mekanismer for endogen smertehemming er altså i beste fall basert på modeller som måler antinocisepsjon. Resultater fra smertemodeller som i stor grad er basert på motoriske responser, er ikke nødvendigvis relevante for human smertefysiologi.

\section{Klinisk relevans}

Placeboanalgesi er potensielt nyttig for enhver kliniker som behandler smerter. Positiv informasjon om behandlingen formidlet på rett måte gir bedre smertedempende effekt enn mer nøytral informasjon formidlet med en liten tvil om behandlingens effekt. Informasjon om potensielle bivirkninger kan gi motsatt effekt via noceboeffekten. Effektsimulering/lurebehandling for å øke placeboeffekten må imidlertid anses som uetisk praksis.

Den analgetiske effekten av betinget smertefull stimulering er vist å være redusert ved en lang rekke kroniske tilstander, som for eksempel fibromyalgi (32), tensjonshodepine (33), migrene (34) og irritabel tarmsyndrom (35). Størrelsen på denne effekten er generelt ikke relatert til graden av smerteplager i disse gruppene. Det er ikke avklart hvorvidt redusert effekt er en årsak til eller et resultat av kroniske smerter. Imidlertid har en studie vist at preoperativt vurdert lav effekt er en risikofaktor for smerter etter torakotomi (36). På den annen side er det holdepunkter for at kirurgisk behandling av koksartrose (37) og seponering av analgetika/triptaner hos pasienter med medikamentoverforbrukshodepine (38) øker effekten. Dette kan indikere at behandling av kroniske smerteplager kan sette kroppen i bedre stand til å takle akutte smerter.

På samme måte som høyt blodtrykk er vist å beskytte mot smerte, er lavt blodtrykk vist å være knyttet til lavere smerteterskel (39). Vi har imidlertid ikke funnet noen studier som systematisk har undersøkt om blodtrykksbehandling per se endrer smerteterskelen.

Ulike former for distraksjon med lyd og bilde under smertefulle inngrep har blant annet vært brukt av tannleger i forbindelse med smertefulle inngrep i munnhulen, og halvering av rapportert smerteintensitet har vært beskrevet (40).

Av de ulike kjente endogene analgetiske mekanismene har enkelte vist seg å være relativt kortvarig (analgesi knyttet til smertefull betinget stimulering og fysisk trening), og av den grunn er disse trolig klinisk mest nyttig i forbindelse med prosedyrerelatert smerte. For kronisk smerte er den potensielle nytteverdien av de ulike endogene smertehemmende mekanismene ikke undersøkt.

\section{Konklusjon}

Kroppens endogene smertehemmende mekanismer kan forsterkes ved positiv informasjon om behandlingen. Teoretisk kan målrettet aktivering av endogene smertehemmende mekanismer som diffus nociseptiv inhiberende kontroll og hypertensjonsrelatert hypoalgesi være nyttig særlig for reduksjon av kortvarige smerter. Det er imidlertid behov for mer klinisk-fysiologisk smerteforskning for å undersøke om ulike teknikker for målrettet aktivering av endogene smertehemmende mekanismer kan bli nyttige $\mathrm{i}$ behandlingen av pasienter med ulike akutte og kroniske smertetilstander.

\section{Oppgitte interessekonflikter: Ingen}

\section{Litteratur}

Melzack R, Wall PD. Pain mechanisms: a new theory. Science 1965; 150: 971-9.

2. Fields HL, Basbaum Al, Heinricher MM. Central nervous system mechanisms of pain modulation. I: McMahon SB, Koltzenburg M, red. Wall and Melzack's textbook of pain. 5. utg. London: Elsevier Churchill Livingstone, 2006: 125-42.

3. Fields H. State-dependent opioid control of pain. Nat Rev Neurosci 2004: 5: 565-75.

4. Yeomans DC, Clark FM, Paice JA et al. Antinociception induced by electrical stimulation of spinally projecting noradrenergic neurons in the $A 7$ catecholamine cell group of the rat. Pain 1992; 48 : 449-61.

5. Le Bars D. The whole body receptive field of dorsal horn multireceptive neurones. Brain Res Brain Res Rev 2002; 40: 29-44.

6. Colloca L, Lopiano L, Lanotte M et al. Overt versus covert treatment for pain, anxiety, and Parkinson's disease. Lancet Neurol 2004; 3: 679-84.

7. Voudouris NJ, Peck CL, Coleman G. The role of conditioning and verbal expectancy in the placebo response. Pain 1990: 43: 121-8.

8. Wager TD, Rilling JK, Smith EE et al. Placeboinduced changes in FMRI in the anticipation and experience of pain. Science 2004; 303: 1162-7.

9. Matre D, Casey KL, Knardahl S. Placebo-induced changes in spinal cord pain processing. J Neurosci 2006; 26: 559-63.

10. Levine JD, Gordon NC, Fields HL. The mechanism of placebo analgesia. Lancet 1978; 2: 654-7.

11. Eippert F. Bingel U, Schoell ED et al. Activation of the opioidergic descending pain control system underlies placebo analgesia. Neuron 2009; 63 533-43.

12. Kong J, Gollub RL, Polich $\mathrm{G}$ et al. A functional magnetic resonance imaging study on the neural mechanisms of hyperalgesic nocebo effect. J Neurosci 2008; 28: 13354-62.

13. Benedetti F, Amanzio M, Vighetti S et al. The biochemical and neuroendocrine bases of the hyperalgesic nocebo effect. J Neurosci 2006: 26 : 12014-22.

14. Piché M, Arsenault M, Rainville P. Cerebral and cerebrospinal processes underlying counterirritation analgesia. J Neurosci 2009: 29: 14236-46.

15. Edwards RR, Ness TJ, Fillingim RB. Endogenous opioids, blood pressure, and diffuse noxious inhibitory controls: a preliminary study. Percept Mot Skills 2004: 99: 679-87.

16. Pud D, Granovsky Y, Yarnitsky D. The methodology of experimentally induced diffuse noxious inhibitory control (DNIC)-like effect in humans. Pain 2009; 144: 16-9.

17. Zamir N, Segal M. Hypertension-induced analgesia: changes in pain sensitivity in experimental hypertensive rats. Brain Res 1979; 160: 170-3.
18. Zamir N, Shuber E. Altered pain perception in hypertensive humans. Brain Res 1980; 201: 471-4. 19. Hagen K, Zwart JA, Holmen J et al. Does hypertension protect against chronic musculoskeletal complaints? The Nord-Trøndelag Health Study. Arch Intern Med 2005; 165: 916-22.

20. Falcone C, Auguadro C, Sconocchia R et al. Sus ceptibility to pain in hypertensive and normotensive patients with coronary artery disease: response to dental pulp stimulation. Hypertension 1997: 30: 1279-83

21. Lima D, Albino-Teixeira A, Tavares I. The cauda medullary ventrolateral reticular formation in nociceptive-cardiovascular integration. An experimental study in the rat. Exp Physiol 2002; 87: 267-74.

22. Dowman R. Attentional set effects on spinal and supraspinal responses to pain. Psychophysiology 2001: 38: 451-64.

23. Bushnell MC, Duncan GH, Hofbauer RK et al. Pain perception: is there a role for primary somatosensory cortex? Proc Natl Acad Sci U S A 1999; 96 : 7705-9.

24. Lewis JW, Cannon JT, Liebeskind JC. Opioid and nonopioid mechanisms of stress analgesia. Science 1980; 208: 623-5

25. King CD, Devine DP, Vierck CJ et al. Differential effects of stress on escape and reflex responses to nociceptive thermal stimuli in the rat. Brain Res 2003; 987: 214-22.

26. Khasar SG, Green PG, Levine JD. Repeated sound stress enhances inflammatory pain in the rat. Pain 2005: 116: 79-86.

27. Simkin $P$, Bolding A. Update on nonpharmacologic approaches to relieve labor pain and prevent suffering. J Midwifery Womens Health 2004; 49: 489-504.

28. Koltyn KF. Analgesia following exercise: a review. Sports Med 2000; 29: 85-98.

29. Tappe A, Klugmann M, Luo C et al. Synaptic scaffolding protein Homer1a protects against chronic inflammatory pain. Nat Med 2006: 12: 677-81.

30. Randich A, Roose MG, Gebhart GF. Characterization of antinociception produced by glutamate microinjection in the nucleus tractus solitarius and the nucleus reticularis ventralis. J Neurosci 1988; 8: 4675-84.

31. Mason P. Contributions of the medullary raphe and ventromedial reticular region to pain modulation and other homeostatic functions. Annu Rev Neurosci 2001; 24: 737-77.

32. Kosek E, Hansson P. Modulatory influence on somatosensory perception from vibration and heterotopic noxious conditioning stimulation (HNCS) in fibromyalgia patients and healthy subjects. Pain 1997. 70: 41-51.

33. Pielsticker A, Haag G, Zaudig M et al. Impairment of pain inhibition in chronic tension-type headache. Pain 2005; 118: 215-23

34. de Tommaso M. Difruscolo O, Sardaro M et al. Effects of remote cutaneous pain on trigeminal laser-evoked potentials in migraine patients. $J$ Headache Pain 2007; 8: 167-74.

35. King CD, Wong F, Currie T et al. Deficiency in endogenous modulation of prolonged heat pain in patients with irritable bowel syndrome and tem poromandibular disorder. Pain 2009; 143: 172-8.

36. Yarnitsky D, Crispel Y, Eisenberg E et al. Prediction of chronic post-operative pain: pre-operative DNIC testing identifies patients at risk. Pain 2008; 138 : 22-8.

37. Kosek E, Ordeberg G. Abnormalities of somatosensory perception in patients with painful osteoarthritis normalize following successful treatment. Eur J Pain 2000; 4: 229-38.

38. Perrotta A, Serrao M, Sandrini G et al. Sensitisation of spinal cord pain processing in medication overuse headache involves supraspinal pain control. Cephalalgia 2009: e-publisert 10.7.2009.

39. Duschek S, Dietel A, Schandry R et al. Increased sensitivity to heat pain in chronic low blood pressure. Eur J Pain 2009; 13: 28-34

40. Furman E, Jasinevicius TR, Bissada NF et al. Virtual reality distraction for pain control during periodontal scaling and root planing procedures. J Am Dent Assoc 2009; 140: 1508-16. 